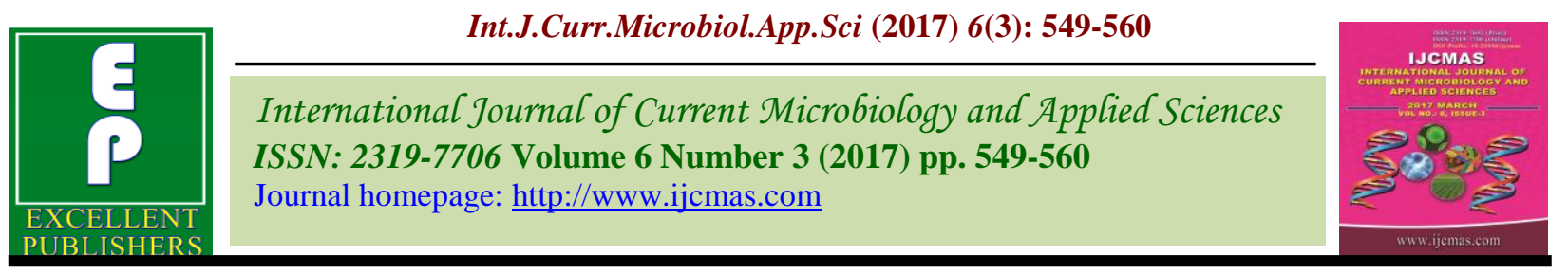

Original Research Article https://doi.org/10.20546/ijcmas.2017.603.064

\title{
Colophospermum mopane - A Potential Host for Rearing Wild Silk Worm (Gonometa rufobrunnea) in Arid Rajasthan
}

\author{
V. Subbulakshmi*, N.D. Yadava, Birbal, M.L. Soni, K.R. Sheetal and P.S. Renjith \\ ICAR-Central Arid Zone Research Institute, Regional Research Station, \\ Bikaner-334004, Rajasthan, India \\ *Corresponding author
}

A B S T R A C T

\begin{tabular}{|c|c|}
\hline & India is the biggest consumer of raw silk and silk fabrics and second largest \\
\hline $\begin{array}{l}\text { Mopane; } \\
\text { wild silkworm; } \\
\text { Gonometa } \\
\text { rufobrunnea, } \\
\text { vanya silk. }\end{array}$ & $\begin{array}{l}\text { and vanya silk (non-mulberry silk). India has vast potential for production of } \\
\text { vanya silks which plays a major role in rural livelihood security. Vanya silk } \\
\text { can also be produced from the cocoons of wild silkworm, Gonometa } \\
\text { rufobrunnea insect. The main food plant of Gonometa rufobrunnea is }\end{array}$ \\
\hline Article Info & $\begin{array}{l}\text { Colophospermum mopane commonly called as mopane. Mopane is a xeric } \\
\text { species of South Africa and introduced in India for sand dune stabilization. }\end{array}$ \\
\hline $\begin{array}{l}\text { Accepted: } \\
\text { 10 February } 2017 \\
\text { Available Online: } \\
10 \text { March } 2017\end{array}$ & $\begin{array}{l}\text { The review discuss about the possibility of rearing Gonometa rufobrunnea in } \\
\text { already available mopane plantations in arid regions of the country to increase } \\
\text { production of vanya silk and to improve the rural economy in arid regions of } \\
\text { India. }\end{array}$ \\
\hline
\end{tabular}

\section{Introduction}

Silk is a textile fibre produced by insects and commonly called as "Queen of Textiles". Since ages, silk and silk products have attracted humankind and have found their place among the most esteemed and rich human fabrics. India is the world's second biggest producer of raw silk and contributes $15.5 \%$ of world silk production. India imports more than 8,500 MT/yr because of increased demand of 25,000MT/yr. By the year 2025 it is expected to increase to $45,000 \mathrm{MT} / \mathrm{yr}$ (Kshirasagar, 2006). So, silk generation has enormous potential in India, which could give extra employment opportunities for upto 6 million rural people mostly women folk
(Ahmed and Rajan, 2011). It is agricultural output based enterprise viz., cocoons and cottage based labour intensive in nature. The silk enterprise includes reeling the cocoons for unwinding the silk filament, weaving, silk knitting, silk wet and processing comprising of degumming, dyeing, printing and finishing other than cloth manufacturing.

The very nature of this industry with its rural based on-farm and off-farm activities and huge employment generation potential has involved the attention of the planners and policy makers to perceive the industry among one of the most appropriate avenues for socio- 
economic development of rural economy like India (Gangopadhyay, 2008). For increasing the silk production we require highly productive and also tolerant silkworm races to adverse climatic conditions and diseases. The wild silkworm (Gonometa rufobrunnea) is one of the silk producing insect which feeds only on mopane (Colophospermum mopane) can be a best addition to already available other non-mulberry silkworms to meet the domestic demand of raw silk. An extensive review on Colophospermum mopane and Gonometa rufobrunnea has been carried out to explore the possibilities of growing wild silkworm in mopane plantation established for sand dune stabilization and afforestation of degraded lands in arid regions of Rajasthan.

\section{Type of silks}

India is a home to a huge variety of silk producing fauna which also includes an remarkable diversity of silk moths. This has made India to achieve the unique distinction of being a maker of all the five commercially traded varieties of natural silks. These are divided into two categories viz., Mulberry silk and Vanya or Non mulberry silk. Those silks produced from the Bombyx mori L. silkworm, which solely feeds on the leaves of the mulberry plant are called as mulberry silk. Most of mulberry silk produced in the world comes from this variety. In India, 92 per cent of the country's total mulberry silk production comes from the states Karnataka, Andhra Pradesh, West Bengal, Tamil Nadu and Jammu and Kashmir together. Non mulberry silk consists of all the other varieties of silk except mulberry silk. Non-mulberry sericulture is generally known as forest or wild sericulture. Tropical and temperate tasar eri and muga are the major non-mulberry silks. Other varieties i.e. fagara, coan, mussel and spider silks are limited interest. Tasar silks alone contribute nearly $95 \%$ of the global production of non-mulberry silks.
Tasar silk is copperish and coarse textured, secreted by the tropical tasar silkworm, Antheraea mylitta which thrives on Asan and Arjun trees (Terminalia sp.) and is mostly used for furnishing and interiors (Gangopadhyay, 2008). Oak tasar is a finer variety of tasar secreted by Antheraea proylei, the temperate tasar silkworm, which nourishes on wild oak plants (Quercus sp.) and is found in large quantity in the subHimalayan belt. Eri silk is a silk spun from open-ended cocoons and produced by the domesticated silkworm, Samia cynthiaricini that feeds mostly on castor leaves. Mugasilk is an exclusive produce of India and preferred attire during festivities especially in Assam. It is golden yellow in colour secreted by Antheraea assamensis. Som (Persea bombycina) and Soalu (Litsea polyantha) are the two major host plants of muga silkworm (Handique and Singh, 2014).

\section{Vanya silk industry in India}

\section{History}

Vanya sericulture remained obscure for quite a while as a selective art of tribal and hill folks inhabiting the Central and North Eastern India. It is in the recent past that this tribal tradition got significance and attracted attention at National level. The eco-friendly nature of the production processes, high production potentialities within the country, enduring interest for vanya silk products outside, women involvement, promoted commercial exploitation of this art, which culminated in the transformation of this age old custom to an industry of enormous potentiality. Vanya silks have been commercially exploited route back in seventeenth Century. The Western World attracted for these alien shaded silks in mid1800 when a widespread silkworm disease affected the whole European sericulture industry. Asia could not supply enough 
mulberry silk to meet the requirements of Europe and North America, accordingly making a market opportunity for vanya silks (CSB, 2017).

\section{Status of vanya silks in India}

\section{Production trends}

Among the different varieties of silk produced in 2015-16, mulberry accounts for $71.79 \%$ (20,478 MT) followed by tasar $9.88 \%(2,819$ MT), eri $17.74 \%(5,060 \mathrm{MT})$ and muga $0.58 \%(166 \mathrm{MT})$ of the total raw silk production of 28,523 MT. During 2015-16 over 2014-15 vanya silk has achieved $9.9 \%$ growth (Table 1) (DGCIS, 2017).

Marketing of vanya silk cocoons and products

In the last two decade steps has been taken to help in marketing of vanya silk cocoons and products viz., establishment of Raw Material Banks (RMB) in vanya sector by Central Silk Board (CSB), Cocoon markets by Department of Sericulture and State government marketing agencies viz., Sericulture Federation (SERIFED), Khadi Village Industries Commission (KVIC) and Tribal Federation (TRIFED). Because of these agencies the bargaining power of primary cocoon producers has been improved. The vanya silk products mainly sarees and fabrics for dress material and furnishings are being marketed by participating in various exhibitions all over India mainly by manufacturers and traders (CSB, 2017).

\section{Export and import of silk goods}

Major markets for Indian silk goods are USA and European countries and also exported to small markets of Asia Region. Fabrics, madeups and readymade garments which account for about $95 \%$ of the total silk goods exports of the country are the major items of India's silk exports. The export earnings from silk goods during 2015-16 were Rs.2495.99cr and Rs. 2829.88 cr. in 2014-15 (Table 2) (DGCIS, 2017). The vanya silk fabrics are being exported mainly from Kolkota, Bhagalpur New Delhi, Mumbai and Bangalore by the established exporters. Vanya silk product contributes approximately $10 \%$ of share of export earnings out of total export of natural silk goods.

India also imports natural silk yarn and silk fabrics apart from raw silk. The import value of silk and silk goods during 2013-14 and 2014-15 are given in table $3.98 \%$ of the total imports include raw silk, silk yarns fabrics and made-ups. During 2014-15, the value of silk goods imports was Rs. 1356.73 cr. compared to Rs. 1357.48 cr. in 2013-14, indicating a decrease of $0.06 \%$ in Rupee terms. Marginal increase of $7.02 \%$ from 3260 MT in 2013-14 to 3489 MT in 2014 has been observed in raw silk import (CSB, 2015).

Moreover, among the non-mulberry varieties, eri has the limitation of higher cost of productions. Tasar is gifted by nature with enormous potential. However, over exploitation and deforestation brought about depletion of non-mulberry food plants. One should not overlook that non-mulberry sericulture holds prodigious potential for the world forestry as a supplementary activity. Vanya (or) Non-mulberry sericulture is a forest based industry specifically suited to the economy and social structure of developing nations on account of its low investment requirement, foreign exchange earning potential and high employment opportunities.

\section{Taxonomic status of the Gonometa rufobrunnea}

The genus Gonometa has two silk producing species of commercial value, Gonometa postica and Gonometa rufabrunnea. In spite a few experts believe $G$. rufobrunnea to be just 
a subspecies of $G$. postica, G. rufobrunnea is recognizable from $G$. postica at every phase of the life-cycle and the larvae feed only on mophane which is rejected by $G$. postica larvae. G. rufobrunnea (Scholtz and Holm, 1985; Hartland-Rowe, 1992) belongs to the order lepidoptera and Family lasiocampidae (Nagaraju and Jolly, 1988). The cocoons of both species are viewed as a profitable natural resource. Notwithstanding comparable cocoon attributes, there are marked differences between the two Gonometa species. The distributions of the species also differ (Pinhey, 1975). Adult male and female moths of $G$. postica have brown forewings, while those of $G$. rufobrunnea are red (Pinhey, 1975). Although the general biology of both species is reasonably known (Pinhey 1975; Scholtz and Holm, 1985; HartlandRowe, 1992), an extensive study on ecology of neither species has been carried out.

\section{Lifecycle of Gonometa rufobrunnea}

The moth has reddish-brown wings looking exactly like dead leaves of mopane. The female is corpulent and twice the size of male. It is nocturnal, lacks functional mouthparts and has shot life span of three to five days, maximum of nine days. The egg stage takes 10-11 days to complete. The eggs are unique, spherical, white in colour with a dark micropyle and a diameter of around $1 \mathrm{~mm}$. The eggs are laid in clusters of $2-25$ eggs (averaging 6 eggs) not generally on the mophane but rather on thin stems of grass or other herbage near mopane trees, however once in a while a cluster is laid upon a mophane leaf. Every female lays around 200 eggs (Hartland-Rowe1, 1992).

In order to investigate the deterministic nature of the choice of pupation site, the betweenhost plant and within host plant distribution of $G$. postica and $G$. rufobrunnea pupae was quantified in Africa. The distribution of both species at these scales was observed to be extraordinarily non-random, with pupae generally preferring toward particular tree attributes and micro-sites. These outcomes now give the premise to suggesting a suitable utilisation strategy for Africa's wild silk moths. In light of the spatial and temporal variability in pupal abundance observed, a stable and predictable cocoon supply for natural harvesting is unlikely. Long-term, broad-scale documentation of Gonometa species population cycles may make it feasible to foresee cocoon availability in the future. Until such research is done, it is prescribed that the current practise of only gathering cocoons from which moths have emerged be continued with (Veldtman, 2005).

\section{Climatic factors}

Climate plays a vital part in regulating the population density of this species. Not only do they directly control the moth emergence timing and the induction and termination of diapause but also affects the timing of availability of food indirectly. Continuous drought can also affect the population by affecting the host plant (Hartland-Rowe1, 1992).

\section{Colophospermum mopane}

\section{Botanical description}

G. rufobrunnea, feed on Colophospermum mopane (Kirk ex Benth.) J. Leonard, a multipurpose tree commonly called mopane, mopanie, rhodesian ironwood, turpentine tree, butterfly tree, red Angolan copal belongs to legume family (Fabaceae). Meaning of this genus is 'oily seed' and refers to the distinct turpentine smell of the oil contained in the seeds. It is one of the most important tree species of the hot and dry areas of southern Africa. Colophon in Ionia was celebrated for its resin; it was the origin place of Homer, so the name connects this African genus with one of the world's great brave stories. The 
particular name, 'mopane' is derived from a Bantu common name for the tree (Van Voorthuizen, 1976). It has been planted in western Rajasthan for stabilizing sand dunes and it performs well in silvopastoral system also.

C. mopane is a deciduous shrub or mediumsized to tall tree from $4 \mathrm{~m}$ to $18 \mathrm{~m}$ tall, normally $\mathrm{I} 0 \mathrm{~m}$, with single or several stems from the base and sparse branches developing upwards. Trunks of large trees have diameters up to $1 \mathrm{~m}$, with bark dull dark to blackish, profoundly and vertically fissured and flaking in limited strips (Timberlake, 1995). Leaves look like camel footprints or butterflies; composed of two asymmetric leaflets, each with a straight inner margin and a curved outer margin, kidney-shaped. C. mopane trees grows in area receives a summer rainfall of $100 \mathrm{~mm}$ and $800 \mathrm{~mm}$ per year and a dry season ranging from 5 to 10 months with a mean annual temperature of -3 to $50 \mathrm{deg}$. C (Palmer and Pitman, 1972). It grows on an wide range of soils, but is commonly found on alluvial soils and on alkaline and poorly drained soils, which it tolerates better than many other species and has a wide attitudinal range (200-1200 m) (Orwa et al., 2009; Timberlake, 1995).

\section{Uses}

C. mopane is a multipurpose trees planted in agroforestry for, soil improvement, fuel wood, fodder, shade, shelter, rehabilitation of degraded soils and stabilization of dry, alkaline soils and sand dunes. The tree regrows after felling and the chemical present in mopnae give resistant against termites and borers which increase its preference in construction purposes. The internal barks are utilized for making ropes, while the external barks are utilized for fuel. High wood density of $(1200 \mathrm{~kg} / \mathrm{m} 3)$ the mopane makes the species durable (Goldsmith and Carter, 1981).
The wood cell of $C$. mopane is stuffed with crystals of calcium oxalate, which results in a dense wood (Prior and Cutler, 1992). Likewise, the secondary metabolites by and large known as extractives, adds to the final density of wood. As $C$. mopane grow in harsh environments, those environmental conditions favours high substance of extractives in the plant. Mopane wood stripped of bark is used with other commonly available tree species to build a variety of structures, including traditional huts (walls and roof structures), grain stores, fences, chicken pens and kraals (Mashabane et al., 2001). It is used for building timbers, flooring, exterior fittings, fences, railway sleepers and furniture, as well as round wood, posts, pit props, and tool handles. Wood is excellent firewood, it burns easily, even when green (Liengme, 1983). It is reported to burn slowly with the remaining coals emitting a lot of heat which is good for long periods of cooking. The ash is used as fertiliser, although this was found not to be a common practice (Madzibane and Potgieter, 1999). A small fibre is said to be obtainable from the bark of this tree. C. mopane is also used for treatment of various animals and human diseases. Seeds are consumed by humans as famine food.

C. mopane taps underground water, which help to break dormancy to produce fresh leaves and consequently making it an important fodder species in times of grass shortage. Crude protein content is $11 \%$ when the leaves are reddish-brown in colour and animals relish the leaves at this stage. Fallen leaves contain crude protein content of around $4 \%$. Old leaves are picked from the ground and eaten. Fresh leaves are not palatable as it contains higher crude protein $(13 \%)$ and have a laxative effect on cattle and also have high tannins (Orwa et al., 2009). Feeding fresh leaves of C.mopane is possible in goats but it can be fed at 35-40 percent of whole ration. The palatability of mopane dry leaves was 
low and decreased with progress of feeding from 15 to 5 per cent from first to fifth week (Mathur et al., 2007).New leaves are utilized to treat animals with sores on their ankles (Mashabane et al., 2001). C. mopane is host tree of mopane moth or head moth (Gonimbrasia belina) caterpillars which feed on its leaves (Ditlhogo et al., 1996). In southern Africa the mopane worms are consumed (Palgrave, 1983) as a nutritional food (Mpuchane et al., 2001) and also provides income through the sale (Shackleton et al., 2000; Kozanayi and Frost, 2002; Gondo et al., 2010) because of rich source of protein. Crude protein content in the caterpillars is assessed at $47.5 \%$ (Orwa et al., 2009).

\section{Silvicultural practices}

C. mopane is a drought tolerant species limited to regions of alluvium and colluvium soils with low to modest precipitation. It grows quickly both vegetatively and by seed. Seeds orthodox in nature yet seeds are sometimes viable for more than one year under natural conditions. Central Arid Zone Research Institute (CAZRI), Jodhpur, Rajasthan reported failure in germination with 8-year-old $C$. mopane seeds (Orwa et al., 2009). Without any seed treatment the seeds grow readily however 24 hours water soaking speeds germination. Seeds can be sown in the polybag in the nursery or directly sown in the pits in the field. C. mopane is the only tree species which exhibited natural regeneration in afforested areas under arid conditions (CAZRI, 1979).

Tree spacing of $5 \times 5 \mathrm{~m}$ is suitable for agroforestry system and $10 \mathrm{x} 4 \mathrm{~m}$ for restoring degraded rangeland. Weeding should be done in the initial few years as the young trees are susceptible to competition. More number of coppice shoots was observed in trees cut at $1 \mathrm{~m}$ over the ground level than
$10 \mathrm{~cm}$ high after three years of planting. However seedlings may have height increments of around $10 \mathrm{~cm}$ per year and grow slowly (Timberlake, 1995). Musvotu et al., (2006) recorded 5-10 t/ha/yr of biomass production in acacia and mopane mixed woodlands with a coppicing cycles of 10-20 years, however more long term research is required on coppice management in mopane plantations. He also observed a significant increase in flowering and fruiting due to thinning as it reduces the inter-tree competition. Root system of $C$. mopane are shallow (30-120 cm deep) and extensive as an adaptation to survive in the arid condition. The roots can take up water from drier soil than contending grasses. The leaves join together and hang straight down under more daylight or water stress conditions (Hocking, 1993).

\section{Pests and diseases}

There are no major diseases in arid regions of the country. In Africa, it is regularly defoliated by larvae of Anomalous emperor moths. 'Mopane bee' additionally makes harm the species to some degree. In some places young seedlings were attacked by termites. In case of such issues, Aldrex powder, BHC or Gammexane ought to be applied in the pits before planting operations (Orwa et al., 2009).

\section{Colophospermum mopane in arid Rajasthan}

Many authors evaluated and reported the performance of Colophospermum mopane in arid western Rajasthan. Among fourteen tree species investigated Prosopis cineraria, Colophospermum mopane and Hardwickia binata which lead to higher built of amino acids, amino sugars, hydrolysable $\mathrm{NH}_{4}-\mathrm{N}$ and total hydrolysable $\mathrm{N}$ are likely to be more useful to the companion crop than rest of the 
species evaluated (Burman et al., 2002). Increase in organic matter, available nitrogen, phosphorus and micronutrients were observed in in silvo pasture plantations of Acacia tortlis, Colophospermum mopane, Hardwickia binata with Cenchrus ciliaris in degraded lands in arid India (Aggarwal et al., 1978). Production potential of silvipastoral systems involving two trees, viz. Colophospermum mopane and Hardwickia binata with buffel grass (Cenchrus ciliaris L.) and sewan grass (Lasiuruss indicus Henr.) and fodder sem (Lablab purpureus L.) as legume were assessed with and without $\mathrm{N}$ application. Significant variation in the growth of Colophospermum mopane was observed due to cropping systems. The average plant height and survival percentage of Colophospermum mopane were higher than Hardwickia binata (Patidar et al., 2008).

Colophospermum mopane was planted in agri-horti-silvi system with citrus and shisham and with intercrops viz., mungbean and cluster bean at CAZRI, Bikaner under sprinkler irrigation system. Colophospermum mopane recorded highest leaf water potential of $-6.99 \mathrm{MPa}$ and both intercrops recorded maximum leaf water potential in Colophospermum mopane intercrop plot (Yadava et al., 2013). Growth of Colophospermum mopane was better with intercrops than the sole trees (without intercrops) but it affected the yield of intercrops due to more competition for moisture with intercrops. The maximum stem girth $(78.00 \mathrm{~cm} ; 74.33 \mathrm{~cm})$ and tree canopy $\left(25.10^{2} ; 24.53 \mathrm{~m}^{2}\right)$ was recorded by Colophospermum mopane respectively when intercropped with mungbean and clusterbean (Yadava et al., 2013).

Litter decomposition of different tree species viz., Acacia senegal, Acacia tortilis, Colophospermum mopane and Dalbergia sissoo were studied by litterbag technique in between the tree stands at CAZRI, Bikaner.
Among all species the $\mathrm{C} / \mathrm{N}$ ratio was highest in Colophospermum mopane and the $\mathrm{N}$ concentration in the leaf litters was $0.99 \%$. Compared to other species the lignin content (34.1\%) was highest in the Colophospermum mopane which makes the litter resistant to decomposition because it binds strongly to organic-N (e.g. aminoacids and proteins) in litter (Palm and Sanchez, 1991). The result indicated that for $99 \%$ decay, litter of Colophospermum mopane would require 588 days at field capacity and 746 days at $50 \%$ field capacity which is the maximum among all the species studied (Soni et al., 2016). In order to rehabilitate the mining area Colophospermum mopane and few other arid tree species were planted at Lignite Mining Backfill in Barmer, Rajasthan Survival of species planted at lignite mine spoil was $82.82 \%$ (Moharana et al., 2016).

In another experiment three tree species, viz. Emblica officinalis, Colophospermum mopane and Hardwickia binata, were planted at AFRI, Jodhpur in agroforestry system with mungbean as intercrop. Colophospermum mopane recorded the second highest intercrop yield of $330 \mathrm{~kg} \mathrm{ha}^{-1}$ (ICFRE 1995). Singh and Singh (2015) reported $51 \%$ more height in Colophospermum mopane in agroforestry than in the alone tree plots. Collar diameter was greater by $63 \%$ in tree-integrated than in the alone tree plots. Maximum crown diameter was recorded by Colophospermum mopane compared to other tree species. He also observed that the roots of 18-year old Colophospermum mopane were more confined to top $80 \mathrm{~cm}$ soil layer and almost parallel to soil surface and appeared to be more competitive in agroforestry system at Jodhpur, Rajasthan. Average total dry biomass ranged between 5.91 to $130.41 \mathrm{~kg}$ per tree. Biomass accumulation in stem was $28.6 \%$, whereas contribution of foliage to the total biomass was $40.2 \%$.

To study the effect of tree integration and 
cropping pattern on land productivity Colophospermum mopane plants were intercropped for seven years. In the treeintegrated plots soil organic matter was increased and available $\mathrm{PO}_{4}$ [sbnd] $\mathrm{P}, \mathrm{NH}_{4}$ [sbnd] $\mathrm{N}$ and $\mathrm{NO}_{3}$ [sbnd] $\mathrm{N}$ were decreased. Added litters and nutrient uptake are the major reasons for these changes. Conclusively, Colophospermum mopane enhances land productivity through increased system production and agriculture yield in the initial 4 - 5 years. In order to reduce the competition for the resources at higher age canopy restructuring and root trenching should be carried out (Singh and Rathod, 2006).

\section{Silk of mopane silk worms}

Gonometa rufabrunnea silk is marginally coarser than B. mori silk, yet finer than other wild silk moth species (Hartland-Rowe, 1992; Freddi et al., 1993). G. rufabrunnea silk dyes very well and has characteristic gold shading (Hartland-Rowe, 1992). As the silk strands are produced from hatched cocoons they are environment cordial and their production does not trade off biodiversity at all.

\section{Opportunities}

It is hoped that the collection and processing of the wild silk moths' cocoons will do much in providing people with an income. And because the cocoons are collected only when the moths have already emerged, the moth population is not affected - unlike the mulberry silk industry, which has led to overexploitation of the insects. The wild silk moth nonetheless has the potential to make as great an economic impact as mulberry silk worm.

Table.1 Raw silk production in India

\begin{tabular}{|l|l|l|l|l|}
\hline & $\mathbf{2 0 1 3 - 1 4}$ & $\mathbf{2 0 1 4 - 1 5}$ & $\mathbf{2 0 1 5 - 1 6}$ & $\mathbf{2 0 1 6 - 2 0 1 7} *$ \\
\hline Mulberry silk & 19,476 & 21,390 & 20,478 & 7,085 \\
\hline Vanya silk & 7004 & 7318 & 8045 & 2242 \\
\hline Total & 26,480 & 28,708 & 28,523 & 9,327 \\
\hline
\end{tabular}

*up to August, 2016

(DGCIS, 2017)

Table.2 Export earnings from silk and silk goods (Value: Crore Rs.)

\begin{tabular}{|l|c|c|c|c|}
\hline Items & $\mathbf{2 0 1 3 - 1 4}$ & $\mathbf{2 0 1 4 - 1 5}$ & $\mathbf{2 0 1 5 - 1 6}$ & $\mathbf{2 0 1 6 - 1 7}$ \\
\hline Natural Silk Yarn & 36.25 & 25.40 & 30.32 & 4.27 \\
\hline Fabrics and Made-up & 1455.63 & 1465.40 & 1280.60 & 186.74 \\
\hline Readymade Garments & 874.00 & 1214.01 & 1078.39 & 470.01 \\
& & & & \\
\hline Silk Carpet & 15.71 & 15.97 & 16.88 & 1.63 \\
& & & & \\
\hline Silk Waste & 99.30 & 109.12 & 89.80 & 43.98 \\
\hline TOTAL & $\mathbf{2 4 8 0 . 8 9}$ & $\mathbf{2 8 2 9 . 8 8}$ & $\mathbf{2 4 9 5 . 9 9}$ & $\mathbf{7 0 6 . 6 3}$ \\
\hline
\end{tabular}


Table.3 Value of Import of silk and silk goods during 2013-14 and 2014-15 (Value: Cr. Rs.)

\begin{tabular}{|l|c|c|c|}
\hline Items & $\mathbf{2 0 1 3 - 1 4}$ & $\mathbf{2 0 1 4 - 1 5}$ & $\begin{array}{c}\text { \% } \\
\text { increase/Decrease }\end{array}$ \\
\hline Raw Silk & $896.44(3260 \mathrm{MT})$ & $970.82(3489 \mathrm{MT})$ & $8.30(7.02)$ \\
\hline Silk Yarn & 100.07 & 103.78 & 3.70 \\
\hline Fabrics and Made-up & 315.32 & 239.16 & -24.15 \\
\hline Readymade Garments & 16.07 & 16.63 & 3.47 \\
\hline Silk Carpet & 0.62 & 0.43 & -30.21 \\
\hline Silk Waste & 28.96 & 25.91 & -10.54 \\
\hline TOTAL & $\mathbf{1 3 5 7 . 4 8}$ & $\mathbf{1 3 5 6 . 7 3}$ & $\mathbf{- 0 . 0 6}$ \\
\hline \multicolumn{2}{|l}{ Note: Figures in parenthesis indicate quantity of raw silk imported. } \\
\hline
\end{tabular}

(CSB, 2015)

The multipurpose tree species $C$. mopane is the best tree species with lot of economic potentials to grow in arid regions and to improve the rural livelihoods. C. mopane plantation can be raised in community land with the cooperation and management of local people. This can be achieved through formation of community co-operatives. After establishment of the plantation, mopane silk worms can be introduced and members of the community co-operatives can be involved in collection of the cocoons, which will then be sold to the silk enterprises. Already available C. mopane plantations in afforested areas, sand dune stabilized areas can also be used for growing mopane silk moth. With this initiative $C$. mopane tree will act as an important source of income for rural communities of arid Rajasthan through collection, cleaning and degumming of the mopane moth's hatched cocoons apart from greening the arid regions of the country.

\section{Future research need}

Bombyx mori L. the domesticated silkworm species, evolved nearly 4600 years prior from the Bombyx mandarina Moore, a wild species, which is a local of China and Palaearctic region (Hampson, 1892; Hirobe, 1968). The eggs of B. mori were initially brought from China into Japan and Korea in the first century and consequently into Middle Eastern and European nations and later into the adjoining nations around China in the 6th century. The chronicled foundation of silkworm passage into India is still a puzzle; and the verifiable proof shows that a prospering silk trade was practicing amongst India and Rome/Greece during Kaniska period (56 B C) (FAO, 2003). Amid eighteenth century, the British control in India, many univoltine and bivoltine silk worm races were introduced from Italy, France, Russia and China, and the races were reproduced and maintained by the farmers (Krishna Rao, 1997) and few of them persisted under Indian climatic condition. Likewise presence of mopane silkworms in Indian condition can be surveyed and multiplied or possibilities for the introduction of mopane silk worms from Africa can be initiated. Further, biology of mopane silkworms, the conditions which must prevail for the growth of the mopane silkworms, successful method of seeding populations, captivity rearing, the factors which induce or terminate diapause, methods to increase cocoon productivity, management techniques for mopane trees, pest-management measures against various pests of mopane and silkworms, formation of village co-operatives 
for growing of mopane silk worms and development of better marketing conditions are the major researchable issues to be considered to increase the wild silk production from mopane and to improve the livelihood status of rural communities in arid Rajasthan.

\section{References}

Aggarwal, R.K., Gupta, J.P., Saxena, S.K. and Muthana, K.D. 1978. Studies on physicchemical and ecological changes under twelve years old five desert trees species of western Rajasthan. Indian For., 102: 863-872.

Ahmed, A. and Rajan, R.K. 2011. Exploration of Vanya Silk biodiversity In North Eastern region of India: Sustainable livelihood And Poverty alleviations. International Conference on Management, Economics and Social Sciences (ICMESS'2011) Bangkok Dec., 2011, pp. 485-489

Burman, U., Praveen Kumar, Harsh, L.N. 2002. Single tree influence on organic forms and transformation of nitrogen in arid soils. J. Indian Soc. Soil Sci., 50(2): 151-158.

CAZRI. 1979. 25 Years ofArid Zone Research, 1952-77. Central Arid Zone Research Institute Jodhpur-342 003.

CSB. 2015. Annual Report, 2014-15, Central Silk Board, Ministry of Textiles, Govt. of India, CSB Complex, BTM Layout, Madivala, Bengaluru-560 068

CSB. 2017. http://www.csb.gov.in/silksericulture/silk/vanya-silk/

DGCIS. 2017. www.dgciskol.nic.in

Ditlhogo, M., Allotey, J., Mpuchane, S., Teferra, S., Gashe, B.A. and Siame, B.A. 1996. Interactions between the mopane caterpillars, Imbrasia belina and its host, Colophospermum mopane in Botswana. In Flower, C., Wardell-Johnson, G. and Jamieson, A. (eds.), Management of mopane in southern Africa. Proceedings of the Workshop held at Ogongo Agricultural College, Northern Namibia, 26th-29th November, 1996, pp. 45-48, University of Namibia, Windhoek.

FAO. 2003. Conservation Status of Sericulture Germplasm Resources in the World - II. Conservation Status of Silkworm (Bombyx Mori) Genetic Resources in the World. Ed. KeeWookSohn. In: Expert Consultation on Promotion of Global Exchange of Sericulture Germplasm, Bangkok, Thailand, September 2002. FAO, Rome.

Freddi, G., Bianchi Svilokos, A., Ishikawa, H. and Tsukada, M. 1993. Chemical composition and physical properties of Gonometa rufobrunnea silk. J. Appl. Polym. Sci., 48(1): 99-106.

Gangopadhyay, D.2008. Sericulture Industry in India - A Review. S\&T for Rural India and Inclusive Growth. India, Science and Technology. NISTADS, New Delhi 110012

http://www.nistads.res.in/indiasnt2008/t6r ural/t6rur16.htm

Goldsmith, B. and Carter, D.T. 1981. The indigenous timbers of Zimbabwe. Forestry Commission, Zimbabwe, Bull. Forestry Res., No 9.

Gondo, T., Frost, P. Kozanayi, W, Stack, J. and Mushongahande, NT. 2010 Linking knowledge and practice: assessing options for sustainable use of mopane worms (Imbrasia belina) in Southern Zimbabwe. J. Sustainable Dev. Afr. 12: 127-145.

Hampson, G.F. 1892. The Fauna of British India including Ceylon and Burma: Moths, Vol. Taylon and Francis London. pp. $31-40$

Handique, P.K. and Singh, R. 2014. Package and Practices for cultivation of perennial Muga silkworm host plant Som (Persea bombycina) Kost Central Silk Board, Central Muga Eri Research and Training 
Institute, Lahdoigarh, Jorhat, Assam. http://www.krishisewa.com/articles/produ ction-technology/386-muga-hostsom.html

Hirobe, T. 1968. Evolution, differentiation and breeding of the silkworm - The Silk Road, past and present. Genetics in Asian countires, XII International Congress of Genetics.

Hocking, D. 1993. Trees for Drylands. Oxford \& IBH Publishing Co. New Delhi.

ICFRE. 1995. Annual Report of Indian Council of Forestry Research \& Education, Dehradun, India.

Kozanayi, W. and Frost, P. 2002. Marketing of mopane worm in southern Zimbabwe. Mopane worm market survey: southern Zimbabwe, pp. 17, Institute of Environmental Studies, University of Zimbabwe.

Krishna Rao, S. 1997. History of silkworm races. In Silkworm Breeding. Edt. G. Sreerama Reddy. Oxford \& IBH Publishing. Co. Pvt. Ltd. New Delhi, pp 3-17.

Kshirasagar, K.G. 2006. Impact of sugarcane farming on economics of sugarcane cultivation in Maharashtra, Gohkale Institute of Politics and Economics.

Liengme, C.A. 1983. A study of wood use for fuel and building in an area of Gazankulu. Bothalia, 14: 245-257.

Madzibane, J. and Potgieter, M.J. 1999. Uses of Colophospermum mopane (Leguminosae: Caesalpinioideae) by the Vhavenda. S. Afr. J. Bot., 65(5 \& 6): 440443.

Mashabane, L.G., Wessels, D.C.J. and Potgieter, M.J. 2001. The utilisation of Colophospermum mopane by the Vatsonga in the Gazankulu region (eastern Northern Province, South Africa) S. Afr. J. Bot., 67: 199-205

Mathur, B.K., Bhati, T.K., and Tewari, J.C. 2006. Comparative palatability of
Prosopis cineraria v/s Colophospermum mopane leaves in lactating Marwar goat in arid region. In: National symposium on livelihood security and diversified farming systems in arid regions January 14-16, 2006. Organized by Arid Zone Research Association of India, CAZRI, Jodhpur, India. No.3-2 pp.51-52.

Moharana, P.C., Santra, P., Singh, D.V., Suresh Kumar, Goyal, R.K., Deepesh Machiwal and Yadav, O.P. 2016. ICARCentral Arid Zone Research Institute, Jodhpur: Erosion Processes and Desertification in the Thar Desert of India. Proc. Indian Natn. Sci. Acad., 82 No. 3 July Spl Issue. pp. 1117-1140. DOI:10.16943/ptinsa/2016/48507

Mpuchane, S.F., Gashe, B.A., Allotey, J., Ditlhogo, M.K., Siame, B.A., Teferra, G., Collison, E.K. and Simpanya, M.F. 2001. Phane: Its exploitation and conservation in Botswana. Technical Bulletin 6. Phane Research Project, Department of Biological Sciences, University of Botswana, pp. 46.

Musvotu, C., Marmot, I., Gondo, T. Ndeinoma, A. and Ntujawo, T. 2006 Reality and preferences in community mopanc (Colophospermum mopane) woodland management in Zimbabwe and Namibia. Int. J. Hum. Soc. Sci., 1: 173176.

Nagaraju, J. and Jolly, M.S. 1988. A preliminary note on the cocoon characters and chromosome number of Gonometa postica (Lepidoptera: Lasiocampidae). Indian J. Seric., 27(2): 149-150.

Orwa, C., Mutua, A., Kindt, R., Jamnadass, R. and Anthony, S. 2009. Agroforestry Database: a tree reference and selection guide version 4.0. http://www.worldagroforestry.org/sites/tr eedbs/treedatabases.asp

Palgrave, K.C. 1983. Trees of southern Africa. 5th Edition. Struik, Cape Town, pp. 959. 
Palmer, E. and Pitman, N. 1972. Trees of Southern Africa Vol. 2. A.A. BalKema Cape Town.

Patidar, M., Rajora, M.P. and Raj Singh. 2008. Forage production potential of different silvi-pastoral systems under arid conditions of Rajasthan. Indian. $J$. Agron., 53(3): 234-238

Pinhey, E.C.G. 1975. Moths of Southern Africa, Tafelberg, Cape Town. Pretoria, Pretoria.

Prior, J. and Cutler, D. 1992. Trees to fuel Africa's fire. New Sci., 1836: 35-39.

Richard Hartland-Rowe. 1992. Biology of the wild silkmoth Gonometa rufobrunnea Aurivillius (Lasiocampidae) in northeastern Botswana, with some comments on its potential as a source of wild silk. Botsw. Not. Rec., 24: 123-133.

RuanVeldtman. 2005. The ecology of southern African wild silk moths (Gonometaspecies, Lepidoptera: Lasiocampidae): consequences for their sustainable use. University of Pretoria

Scholtz, C.H. and Holm, E. 1985. Insects of Southern Africa, University of Pretoria,

Shackleton, S., Shackleton, C., Netshiluvhi, T., Geach, B. and Balance, A. 2000. How valuable are our woodlands for sustainable rural livelihoods? Local-level valuation of woodland resources from three villages in South Africa, In Seydack, A.H.W., Vermeulen, W.J. and Vermeulen, C. (eds.), Towards Sustainable Management Based on
Scientific Understanding of Natural Forests and Woodland, Natural Forest and savanna Woodlands Symposium II. 3-9, pp. 305-321, Knysma, South Africa.

Singh, G. and Bilas Singh. 2015. Rooting pattern and equations for estimating biomasses of Hardwickia binata and Colophospermum mopane trees in agroforestry system in Indian desert. Research \& Reviews: J. Bot. Sci., 4(1): 30-40.

Singh, G. and Rathod, T.R. 2006. Growth, production and resource use in Colophospermum mopane based agroforestry system in north-western India. Arch. Agron. Soil Sci., 53: 75-88.

Soni, M.L., Yadava, N.D. and Bhardwaj, S. 2016. Dynamics of leaf litter decomposition of four tree species of arid western Rajasthan under varying soil moisture regimes. Int. J. Trop. Agric., 34(4): 955-960.

Timberlake, J.R. 1995 Colophospermum mopane, Annotated Bibliography and Renew. The Zimbabwe Bulletin of Forestry Res., 11: Forestry Commission, Harare, pp. 49.

Van Voorthuizen, E.G. 1976. The mopane tree. Botsw. Not. Rec., 8: 223-238.

Yadava, N.D., Soni, M.L., Nathawat, N.S. and Birbal. 2013. Productivity and growth indices of intercrops in AgriHorti-Silvi system in arid Rajasthan. Ann. Arid. Zone, 52(1): 61-65.

\section{How to cite this article:}

Subbulakshmi, V., N.D. Yadava, Birbal, M.L. Soni, K.R. Sheetal and Renjith, P.S. 2017. Colophospermum mopane - A Potential Host for Rearing Wild Silk Worm (Gonometa rufobrunnea) in Arid Rajasthan. Int.J.Curr.Microbiol.App.Sci. 6(3): 549-560.

doi: https://doi.org/10.20546/ijcmas.2017.603.064 